Copyright ( $) 2020$ University of Bucharest Printed in Romania. All rights reserved

ISSN print: $1224-5984$

ISSN online: 2248-3942
Rom Biotechnol Lett. 2020; 25(3): 1621-1627 doi: $10.25083 / \mathrm{rbl} / 25.3 / 1621.1627$

Received for publication, July, 15, 2017

Accepted, August, 20, 2018

Original paper

\title{
Seed germination of some medicinal plant species for conservative purpose
}

\author{
RODICA CATANĂ ${ }^{1 *}$ MĂDĂLINA LAZĂR ${ }^{2}$, IRINA HOLOBIUC ${ }^{1}$, \\ LARISA FLORESCU ${ }^{1}$
}

${ }^{1}$ Institute of Biology Bucharest, Romanian Academy, 296 Splaiul Independenței St., 060031, P.O. Box 56-53, Bucharest, Romania

${ }^{2}$ University of Bucharest, Faculty of Biology, 1-3 Portocalelor Entrance, sector 6, Bucharest, România

\begin{abstract}
Due to the overexploitation, many medicinal plants are in decline. Enhancing the seed germination and the vigorous seedlings production is crucial for their cultivation and for ex situ conservation. Seven medicinal plant species were studied concerning seed germination as effect of different treatments (sterilization procedures and stimulation of germination). Seed sterilization with $\mathrm{HgCl}_{2} 0.1 \%$ for 12 minutes was effective for controlling microbial and fungal contamination in all tested medicinal species. In vitro conditions were efficient for seed germination for 4 species. The stimulation treatments tested $\left(\mathrm{KNO}_{3}\right.$ $0.1 \%, \mathrm{NaCl} 0.5 \%$ and $\mathrm{GA}_{3} 0.5 \%$ ) determined an improvement of seed germination capacity compared with untreated seeds.
\end{abstract}

Keywords Medicinal plant, germination, stimulation, conservation.

To cite this article: CATANĂ R, LAZĂR M, HOLOBIUC I, FLORESCU L. Seed germination of some medicinal plant species for conservative purpose. Rom Biotechnol Lett. 2020; 25(3): 1621-1627. DOI: 10.25083/rbl/25.3/1621.1627

$\lambda$ *Corresponding author: RODICA CATANĂ, Institute of Biology Bucharest, Romanian Academy, 296 Splaiul Independenței St., 060031, P.O. Box 56-53, Bucharest, Romania

E-mail: catanarodica@yahoo.com 


\section{Introduction}

The medicinal plant species represent a consistent part of the natural biodiversity. In May 2015, an IUCN report showed that Europe's medicinal plants are in decline due to collection of plants from the wild (for their medicinal value, ornamental and horticultural plant trade) (ALLEN \& al [1]). In our days, $\sim 80 \%$ of the people use medicinal plant species (crude materials, processed products like pharmaceuticals, herbal remedies, teas, spirits, cosmetics, sweets, dietary supplements, insecticides etc.) for their primary health care (ARCEUSZ \& al [2]).

In România almost 900 plant species represent medicinal flora (MUNTEAN [3]). The research directions in these species were focused on their biology, the content of active ingredients and the improvement of culture technology (MUNTEAN [3]).

Three from the selected species are included in the European Red List of Medicinal Plants like least concern (Agrimonia eupatoria, Cnicus benedictus, Geum urbanum) (ALLAN et al [1]). The others, Foeniculum vulgare and Hyssopus officinalis are plants produced at commercial scale. F. vulgare is characterised by poor seed germination (TAHAEI et al [4]).

According to Guidelines on the conservation of medicinal plants [5], the strategies used for the conservation of medicinal plant species applied over the world are represented by in situ and ex situ strategies. The ex situ conservation was classified as in vivo (botanical gardens, field cultures, seed banks) and in vitro (tissue cultures, artificial seeds, cryopreservation) methods. The plant cells and tissues culture technologies offer a great opportunity to exploit the medicinal plants (SHARMA \& al [6]).

Seed germination and seedling establishment are the initial stages of plant development. These processes are unpredictable over space and time. The germination process is specific for each species, depending on different factors like seed maturity, physical conditions (temperature and humidity), harvesting methods, transport and maintenance. In the case of medicinal plants, there is the possibility that seeds can germinate only in the native environment and fail to germinate under the laboratory conditions (GUPTA [7]). Knowledge of the seeds germination of medicinal plants has proved to be useful in development of appropriate conservation strategies (KANDARI \& al [8]).

Low germination rates (frequently result from fungal infection or mechanical damage) or specific ecological requirements may affect the cultivation of some herbs
(VINES [9]). Enhancing the seeds germination and developing of the vigorous seedlings is crucial for an ex situ conservation strategy. The first step of in vitro cultures establishment is the sterilization - process consisting in different treatments having as effect explants free of contamination; viable decontaminated explants are used further for the initiation of tissues culture. When in case of conventional methods, a low rate or no germination was registered, in vitro techniques may enhance the germination process (FAY [10]).

The aim of the present study was to check and improve the seed germination capacity of some medicinal plant for conservative purpose.

\section{Materials and Methods}

Mature seeds from different species of medicinal plants belonging to four families (Table 1) were tested concerning the germination capacity.

The seeds of $F$. vulgare, $P$. anisum and $H$. officinalis were bought from market, in 2014 and others (A. eupatoria, C. benedictus, G. urbanum, C. sativum) were kindly provided by Nicoleta Constantin in 2012, from Botanical Garden, Bucharest.

All seeds were hand sorted to select undamaged seeds. For germination experiments were used 75 seeds in 3 replications/ each treatment. After treatments, seeds were inoculated in distilled water, on filter paper in Petri dishes in culture chamber at $25^{\circ} \mathrm{C}$ and a photoperiod of $16 / 8$ and illumination at 1500 lux. Germinated seeds were counted every day. A seed was considered germinated when the tip of the radicle had grown free of the seed coat.

\section{Experiment 1: Seed germination in vitro and in vivo}

To compare the seed germination capacity in 7 medicinal plant species, in vitro and in vivo conditions were tested, temperature and illumination regime being the same $\left(25^{\circ} \mathrm{C}\right.$ and $16 / 8$ hours photoperiod, 1500 lux illumination).

For in vitro germination, all seeds were sterilized. Steps of sterilization protocol consisted in washing in running tap water (for 2-3 hours), the immersion in ethanol $70^{\circ}$ (30 seconds), in the treatment with $\mathrm{HgCl}_{2}$ $0.1 \%$, (for 12 minutes) followed by three washing in sterile distilled water.

For in vivo germination, unsterilized seeds were placed on filter paper discs wetted with distilled water in placed in $10 \mathrm{~cm}$ Petri dishes. 
Table 1. The medicinal plant species tested for seed germination capacity

\begin{tabular}{|c|c|c|c|c|}
\hline Plant species & Family & Life cycle & Used for & Seeds aspect \\
\hline $\begin{array}{l}\text { Agrimonia } \\
\text { eupatoria } \mathrm{L} .\end{array}$ & Rosaceae & perennial & $\begin{array}{l}\text { disorders related to the liver, } \\
\text { bile, gastrointestinal, } \\
\text { respiratory tract }\end{array}$ & \\
\hline $\begin{array}{c}\text { Cnicus } \\
\text { benedictus } \mathrm{L} .\end{array}$ & Asteraceae & annual & $\begin{array}{l}\text { In vitro antibacterial activity } \\
\text { against Bacillus subtilis, } \\
\text { Brucella species, E. coli, } \\
\text { Proteus species, } P \text {. } \\
\text { aeruginosa, } \text { S. aureus, } \\
\text { Streptococcus faecalis, anti- } \\
\text { HIV, anticancer agents }\end{array}$ & \\
\hline $\begin{array}{c}\text { Geum } \\
\text { urbanum L. }\end{array}$ & Asteraceae & perennial & $\begin{array}{l}\text { rheumatism, gout, infections, } \\
\text { fever }\end{array}$ & \\
\hline $\begin{array}{l}\text { Coriandrum } \\
\text { sativum } \mathrm{L} .\end{array}$ & Apiaceae & annual & $\begin{array}{l}\text { cold, seasonal fever, stomach } \\
\text { disorders, against worms, } \\
\text { rheumatism and pain in the } \\
\text { joints }\end{array}$ & \\
\hline $\begin{array}{c}\text { Foeniculum } \\
\text { vulgare Mill. }\end{array}$ & Apiaceae & perennial & $\begin{array}{l}\text { antioxidant, anti- } \\
\text { inflammatory, antimicrobial, } \\
\text { estrogenic, diuretic, } \\
\text { antithrombotic, } \\
\text { hepatoprotective, memory } \\
\text { enhancing, antimutagenic }\end{array}$ & \\
\hline $\begin{array}{l}\text { Pimpinella } \\
\text { anisum } \mathrm{L} .\end{array}$ & Apiaceae & annual & $\begin{array}{l}\text { analgesic, carminative, } \\
\text { aromatic, disinfectant, } \\
\text { diuretic }\end{array}$ & \\
\hline $\begin{array}{c}\text { Hyssopus } \\
\text { officinalis L. }\end{array}$ & Lamiaceae & perennial & expectorant, antiseptic & \\
\hline
\end{tabular}

\section{Experiment 2: Seed germination improvement}

Among the species analyzed, were chosen two species, one with no germination in vivo and low in vitro response (C. sativum) and one without any positive germination response $(C$. benedictus). For these species, some stimulation treatments were applied to improve the seeds germination. Seeds were maintained in $\mathrm{KNO}_{3} 0.1 \%$, $\mathrm{NaCl} 0.5 \%$ and $\mathrm{GA}_{3} 0.5 \%$ solutions for 3 days at room temperature. The control was represented by seeds cultured on filter paper with distilled water for 3 days without any treatment. No sterilization protocol was used.

After stimulation of germination during 3 days, the seeds (treated and untreated) were inoculated in a substrate consisted in ground and perilte mix in equal parts. Seeds were periodically wetted with tap water without any growth factors or stimulants.

The recorded parameters were the final germination percentage (mean value \pm standard error) and mean germination time calculated after formulas:

Final germination percentage $=$ total number of germinated seeds/total number of seeds X 100 .

Mean germination time $=\Sigma(\mathrm{nT}) / \Sigma \mathrm{N}$ (ELLIS \& ROBERTS [11]), where $\mathrm{n}=$ number of seeds newly germinated at time $\mathrm{T}$ at $25^{\circ} \mathrm{C} ; \mathrm{T}=$ time (hours, days) from the beginning of the germination test, $\mathrm{N}=$ final germination.

The plants obtained from germinated seeds were further used as sources of explants for in vitro multiplication. 
The photos were taken with a Panasonic DMCLS80 camera. The results were statistically analyzed using ANOVA from Daniel's XL Toolbox version 6.52 (http://xltoolbox.sourceforge.net). A posthoc test (Bonferonni-Holm) was applied to check the significant differences among means.

\section{Results and Discussion}

In the present study, aspects concerning seeds germination in seven medicinal plants were evaluated. In the first experiment, seeds were sterilized. It is known that seeds collected from the natural habitats are often contaminated with exogenous and endogenous microbial contaminants (HALLOIN [12]; AHMAD \& al [13]). The seeds sterilization is a prerequisite for successful in vitro germination. Agents as ethanol, sodium hypochlorite, calcium hypochlorite, chlorine gas and mercuric chloride have been widely used for surface sterilization of parts of the plant and seed material of various species (TALEI \& al [14]; DAUD \& al [15]; BARAMPURAM \& al [16]).

In our experiment, although $\mathrm{HgCl}_{2}$ is a toxic agent, at the level used $(0.1 \%)$ and time of exposure (12 minutes) was effective for controlling microbial and fungal contamination in all medicinal plant species tested. Previous works reported that treatment with $\mathrm{HgCl}_{2}$ at $0.1-0.2 \%$ for 10-15 minutes was effective for surface sterilization of other like Aquilaria agallocha (HE \& al [17]) and Aquilaria sinensis (SHU \& al [18]).

Germination percentage recorded in vivo and in vitro conditions (Table 2) shows that in vitro culture conditions had a stimulatory effect in the case of Agrimonia eupatoria, Geum urbanum, Coriandrum sativum and Pimpinella anisum seeds.

Table 2. Germination percentage of the tested medicinal plant species in vitro and in vivo conditions

\begin{tabular}{|c|c|c|c|c|}
\hline Medicinal plant species & Treatments & $\begin{array}{c}\text { Germination } \\
\text { percentage }\end{array}$ & $\mathbf{F}$ & $\mathbf{P}$ \\
\hline \multirow[t]{2}{*}{ Agrimonia eupatoria } & in vivo & $0^{\mathrm{a}}$ & \multirow[b]{2}{*}{57.558} & \multirow[b]{2}{*}{$3.20549 \mathrm{E}-12$} \\
\hline & in vitro & $40.9^{\mathrm{b}}$ & & \\
\hline \multirow[t]{2}{*}{ Geum urbanum } & in vivo & $0^{\mathrm{a}}$ & \multirow[b]{2}{*}{57.558} & \multirow[b]{2}{*}{$3.20549 \mathrm{E}-12$} \\
\hline & in vitro & $43.47^{\mathrm{b}}$ & & \\
\hline \multirow[t]{2}{*}{ Hyssopus officinalis } & in vivo & $16.66^{\mathrm{a}}$ & \multirow[b]{2}{*}{14.062} & \multirow[b]{2}{*}{0.000} \\
\hline & in vitro & $0^{\mathrm{b}}$ & & \\
\hline \multirow[t]{2}{*}{ Coriandrum sativum } & In vivo & $0^{\mathrm{a}}$ & \multirow[b]{2}{*}{11.363} & \multirow[b]{2}{*}{0.000} \\
\hline & in vitro & $13.63^{\mathrm{b}}$ & & \\
\hline \multirow[t]{2}{*}{ Foeniculum vulgare } & In vivo & $44^{\mathrm{a}}$ & \multirow[b]{2}{*}{28.971} & \multirow[b]{2}{*}{ 2.77284E-07 } \\
\hline & in vitro & $7,14^{\mathrm{b}}$ & & \\
\hline \multirow[t]{2}{*}{ Pimpinella anisum } & In vivo & $0^{\mathrm{a}}$ & \multirow[b]{2}{*}{6,428} & \multirow[t]{2}{*}{0,012254} \\
\hline & in vitro & $8.82^{\mathrm{b}}$ & & \\
\hline \multirow[t]{2}{*}{ Cnicus benedictus } & In vivo & 0 & & \\
\hline & in vitro & 0 & & \\
\hline
\end{tabular}

Values having the same letter are not significantly different at 0.05 significance level.

The final germination percentage varied between $7.14 \%$ for $F$. vulgare and $43.4 \%$ for G. urbanum. Using Bonferonni-Holm test showed significant differences between sterilized and unsterilized seeds in the case of Hysopus officinalis, Coriandrum sativum, Foeniculum vulgare $(\mathrm{p}<0.0002)$, Pimpinella anisum (at $\mathrm{p}<0.01)$ (Table 2). Seeds of Cnicus benedictus did not germinated in the first experiment.

This lower germination percentage could be attributed to factors such as lack of nutrients, seeds being inoculated in distilled water without growth factors or germination enhancing factors.

Seeds inoculated in vivo, at the same temperature, humidity, illumination and substrate, but without sterilization, did not germinate in five tested species. Only in the case of $F$. vulgare (44\%) and H. officinalis (16.66\%) the seeds germinated.
Our results concern the efficiency of in vitro conditions than in vivo are in accordance with studies about Cassia alata seed germination (THIRUPATHI \& al [19]). Asparagus racemosus (RAGHAV \& KASERA [20]) and Alstroemeria ligtu hybrid (NASRI \& al [21]) seeds germination was improved by in vitro conditions.

In the case of fennel seeds, it was demonstrated that the optimum temperature for germination is around $22^{\circ} \mathrm{C}$ with small differences for each variety (THOMAS [22]). It was previously reported that the fennel seeds need some treatments to increase the germination rate (NEACŞU $\&$ al [23]). In our experiment, seed germination was low both in vivo (44\%) and in vitro (7.14\%) (Table 2). In the case of this species, is possible that sterilization with $\mathrm{HgCl}_{2}$ inhibited the seed germination.

Usually, Agrimonia eupatoria seeds germinate in 2-6 weeks at $13^{\circ} \mathrm{C}$ (RICE [24]). In our experiment, seeds 
were collected in 2012 and were stored at room temperature for 2 years. No seed germination was observed at $25^{\circ} \mathrm{C}$, neither control seeds nor seeds treated with stimulatory treatments. After in vitro procedures (sterilization with ethanol and $\mathrm{HgCl}_{2}$ at $25^{\circ} \mathrm{C}$ ) $40.9 \%$ of Agrimonia seeds germinated. An explanation of in vitro seed germination in this species might be that sterilization with ethanol and $\mathrm{HgCl}_{2}$ break the dormancy of zygotic embryos. These results are accordingly with others authors (JEAVONS
\& JARVIS [25]) which used a treatment with ethanol and mercuric chloride to break the dormancy of intact hazel seeds.

In the second experiment, the effects of stimulatory treatments $\left(\mathrm{KNO}_{3}, \mathrm{NaCl}\right.$ and $\left.\mathrm{GA}_{3}\right)$ applied in vivo were analyzed (Table 3 ). The stimulation treatments have generally been applied to enhance seed germination (JOSHI \& DHAR [26]) and to increase seedling vigor (LEITE \& al [27]).

Table 3. Seeds germination and applied treatments for $C$. benedictus and $C$. sativum

\begin{tabular}{|l|l|l|}
\hline \multicolumn{1}{|c|}{ Medicinal plant species } & \multicolumn{1}{|c|}{ Treatments } & \multicolumn{1}{c|}{ Mean germination } \\
\hline Cnicus benedictus & $\mathrm{Control}$ & $0 \pm 0^{\mathrm{a}}$ \\
\cline { 2 - 3 } & $\mathrm{KNO}_{3} 0.1 \%$ & $0.671 \pm 0.47^{\mathrm{b}}$ \\
\cline { 2 - 3 } & $\mathrm{NaCl} 0.5 \%$ & $0.315 \pm 0.46^{\mathrm{c}}$ \\
\cline { 2 - 3 } Coriandrum sativum & $\mathrm{GA}_{3} 0.5 \%$ & $0.644 \pm 0.48^{\mathrm{c}}$ \\
\cline { 2 - 3 } & $\mathrm{Control}$ & $0 \pm 0^{\mathrm{a}}$ \\
\cline { 2 - 3 } & $\mathrm{KNO}_{3} 0.1 \%$ & $0.671 \pm 0.47^{\mathrm{b}}$ \\
\cline { 2 - 3 } & $\mathrm{NaCl} 0.5 \%^{\mathrm{c}} 0.63 \pm 0.44^{\mathrm{c}}$ \\
\cline { 2 - 3 } & $\mathrm{GA}_{3} 0.5 \%$ & $0.329 \pm 0.47^{\mathrm{c}}$ \\
\hline
\end{tabular}

Values having the same letter are not significantly different at 0.05 significance level.

In our experiments, the treatments with $\mathrm{KNO} 3, \mathrm{NaCl}$ or $\mathrm{GA}_{3}$ were effective in improving seed germination. Seeds of Coriandrum sativum exposed at $\mathrm{KNO}_{3} 0.1 \%$ and $\mathrm{GA}_{3} 0.5 \%$ showed an improved germination capacity (68\%) comparing with control. In the case of Cnicus benedictus the highest final germination percentage $(67 \%)$ was recorded for seeds soaked in $0.5 \% \mathrm{GA}_{3}$. A lower germination $(33.33 \%)$ was recorded in the case of seeds treated with $0.5 \% \mathrm{NaCl}$. The results showed that there are significant differences between treated and untreated seeds for both species Coriandrum sativum and Cnicus benedictus (Table 4).

Table 4. Result of posthoc test, showing the significance differences between stimulation treatments (using Daniel's XL Toolbox version 6.52).

\begin{tabular}{|l|l|c|c|c|c|}
\hline \multicolumn{2}{|c|}{} & \multicolumn{2}{c|}{ Coriandrum sativum } & \multicolumn{2}{c|}{ Cnicus benedictus } \\
\hline \multicolumn{2}{|l|}{} & Critical & P & Critical & P \\
\hline Control & $\mathrm{KNO}_{3} 0.1 \%$ & 0.008 & 0.000 & 0.008 & 0.000 \\
\hline Control & $\mathrm{GA3} 0.5 \%$ & 0.01 & 0.000 & 0.01 & 0.000 \\
\hline Control & $\mathrm{NaCl} 0.5 \%$ & 0.016 & 0.000 & 0.0125 & 0.000 \\
\hline $\mathrm{KNO}_{3} 0.1 \%$ & $\mathrm{NaCl} 0.5 \%$ & 0.012 & 0.000 & 0.016 & 0.000 \\
\hline $\mathrm{NaCl} 0.5 \%^{2}$ & $\mathrm{GA3} 0.5 \%$ & 0.05 & 0.377 & 0.025 & 0.000 \\
\hline $\mathrm{KNO}_{3} 0.1 \%$ & $\mathrm{GA3} 0.5 \%$ & 0.025 & 0.000 & 0.05 & 0.734 \\
\hline
\end{tabular}

There are several studies concerning seed germination improved with $\mathrm{KNO}_{3}$ and $\mathrm{NaCl}$ solutions in some medicinal plants (GUPTA [7]; SHIVKUMAR \& al [28]; KAMBIZIA \& al [29]; KULKARNI \& al [30]; FARIMAN $\&$ al [31]).

The shortest mean germination time was registered in the case of Cnicus benedictus treated with $0.5 \% \mathrm{GA}_{3}$ (13,5 days). With the same treatment, seeds of Coriandrum sativum starts to germinated after 16 days. After treatment with $0.5 \% \mathrm{NaCl}$, germination capacity starts after 36 days.

Our results are in accordance to other studies which showed that potassium nitrate treatment increased seeds germination in Avena fatua (HILTON [32]), Hypericum aviculariifolium (ÇIRAK \& al [33]), chicory (TZORTZAKIS [34]), Foeniculum vulgare and Cuscuta epithymum (TAVILI \& al [35]). 


\section{Conclusion}

Our results showed that controlled conditions assured by in vitro techniques were efficiently for seed germination for almost species tested. Seeds of Foeniculum vulgare may be sensible at $\mathrm{HgCl}_{2}$, in vitro germination being inhibited. Cnicus benedictus seeds did not germinate in vivo and in vitro conditions, only stimulatory treatments determined an improvement of the germination capacity. Treatment with $\mathrm{KNO}_{3}$ positively influenced the germination of Coriandrum sativum and Cnicus benedictus.

\section{Acknowledgements}

The study was funded by project no. RO1567IBB06/2015 from the Institute of Biology Bucharest of Romanian Academy and is part of the Master degree thesis of Miss Lazăr Mădălina.

\section{References}

1. D. ALLEN, M. BILZ, D.J. LEAMAN, R.M. MILLER, A. TIMOSHYNA, J. WINDOW. European Red List of Medicinal Plants. Luxembourg: Publications Office of the European Union (2014).

2. A. ARCEUSZ, I. RADECKA, M. WESOLOWSKI. Identification of diversity in elements content in medicinal plants belonging to different plant families. Food Chemistry, 120: 52-58 (2010).

3. L.S. MUNTEAN. One hundred ten years of research on medicinal plants, at the agronomy in Cluj (1904-2014). Hop and Medicinal Plants, XXII (1-2): 7-16 (2014).

4. A. TAHAEI, A. SOLEYMANI, M. SHAMS. Seed germination of medicinal plant, fennel (Foeniculum vulgare Mill), as affected by different priming techniques. Applied Biochemistry and Biotechnology, 180(1): 2-40 (2016).

5. Guidelines on the Conservation of Medicinal Plants, Published by The International Union for Conservation of Nature and Natural Resources (IUCN), Gland, Switzerland, in partnership with The World Health Organization (WHO), Geneva, Switzerland, and WWF World Wide Fund for Nature, Gland, Switzerland (1993).

6. S. SHARMA, N. RATHI, B. KAMAL, D. PUNDIR, B. KAUR, S. ARYA. Conservation of biodiversity of highly important medicinal plants of India through tissue culture technology - a review. Agriculture and biology journal of America, 1(5): 827-833 (2010).

7. V. GUPTA. Seed germination and dormancy breaking techniques for indigenous medicinal and aromatic plants. Journal of Medicinal and Aromatic Plants Science, 25: 402-407 (2003).
8. L.S. KANDARI, K.S. RAO, K. CHAUHAN, R.K. MAIKHURI, V.K. PUROHIT, P.C. PHONDANI, K.G. SAXENA. Effect of presowing treatments on the seed germination of two endangered medicinal herbs of the Himalaya (Angelica glauca Edgew and Pleurospermum angelicoides Wall. Ex DC. Benth. Ex C.B. Clarke). Proc. Indian Nat. Sci. Acad., 73: 11-16 (2007).

9. G. VINES. Herbal harvests with a future: towards sustainable sources for medicinal plants. Plantlife International (2004).

10. M.F. FAY. Conservation of rare and endangered plants using in vitro methods. In vitro Cell. Dev. Biol., 28: 1-4 (1992).

11. R.H. ELLIS, E.H. ROBERTS. Towards a rational basis for testing seed quality. In Seed Production, Hebblethwaite P.D. eds., Butterworths, London, (1980).

12. J.M. HALLOIN. Postharvest infection of cottonseed by Rhizopus arrhizus, Aspergillus niger, Aspergillus flavus. Phytopathology, 65: 1229-1232 (1975).

13. F. AHMAD, G.J. DAGLISH, A.W. RIDLEY, G.H. WALTER. Responses of Tribolium castaneum to olfactory cues from cotton seeds, the fungi associated with cotton seeds, and cereals. Entomol. Exp. Appl., 145: 272-281 (2012).

14. D. TALEI, A. VALDIANI, M.P. ABDULLAH, S.A. HASSAN. A rapid and effective method for dormancy breakage and germination of King of Bitters (Andrographis paniculata Nees.) seeds. Maydica, 57(2): 98-105 (2012).

15. N.H. DAUD, S. JAYARAMAN, R. MOHAMED. An improved surface sterilization technique for introducing leaf, nodal and seed explants of Aquilaria malaccensis from field sources into tissue culture. Asian Pac. J. Mol. Biol. Biotechnol., 20: 55- 58 (2012).

16. S. BARAMPURAM, G. ALLEN, S. KRASNYANSKI. Effect of various sterilization procedures on the in vitro germination of cotton seeds. Plant Cell. Tiss. Organ. Cult., 18: 179-185 (2014).

17. M.L. HE, S.Y. QI, L.J. HU. Rapid in vitro propagation of medicinally important Aquilaria agallocha. Journal of Zhejiang University Science, 6(8): 849-852 (2005).

18. Y.Q. SHU, L.H. MENG, D.L. LI, H.Z. CHUAN, J.H. LAN, Z.Z. HUI. Production of 2-(2-phenylethyl) chromones in cell suspension cultures of Aquilaria sinensis. Plant Cell. Tiss. Org., 83: 217-221 (2005).

19. M. THIRUPATHI, M.K. KUMAR, D. SRINIVAS, K. RAJENDAR, K.R. JAGANMOHAN. A study on seed germination of Cassia alata Linn an antiallergenic plant. Journal of Phytology, 4(5): 13-15 (2012).

20. A. RAGHAV, P.K. KASERA. Seed germination behavior of Asparagus racemosus (Shatavari) under 
in-vivo and in-vitro conditions. Asian Journal of Plant Science and Research, 2(4): 409-413 (2012).

21. F. NASRI, N. GHADERI, J. MOHAMMADI, S.N. MORTAZAVI, K.S. MAHMOOD. The effect of gibberellic acid and stratification on germination of Alstroemeria (Alstroemeria ligtu hybrid) seed under in vitro and in vivo conditions. Journal of Ornamental Plants, 3(4): 221-228 (2013).

22. T.H. THOMAS. Responses of Florence fennel (Foenicuhm vulgare azoricum) seeds to light, temperature and gibberellin A4/7. Plant Growth Regul., 14: 139-143 (1994).

23. V.I. NEACŞU, A.S. APAHIDEAN, A.M. HUSTI, R. CICEVAN. Study of fennel seed germination (Foeniculum vulgare var. Azoricum). Agriculture Science and Practice, 1(2): 19-22 (2015).

24. G. RICE. Editor, Growing from Seed. Volume 1. Publisher: Thompson and Morgan (1987).

25. R.A. JEAVONS, B.C. JARVIS. The breaking of dormancy in hazel seed by pretreatment with ethanol and mercuric chloride. New Phytol., 96: 551-554 (1984).

26. M. JOSHI, U. DHAR. Effect of various pre-sowing treatments on seed germination of Heracleum candicans Wall. Ex DC: a high value medicinal plant. Seed Sci. Technol., 31: 737-743 (2003).

27. V.M. LEITE, C.A. ROSOLEM, J.D. RODRIGUES. Gibberellin and cytokinin effects on soybean growth. Sci. Agric., 60: 537-541 (2003).

28. V. SHIVKUMAR, R. ANANDLAKSHMI, R.R. WARRIER, M. TIGABU, P.C. ODEN, S.N. VIJAYACHANDRAN, S. GEETHA, B.G. SINGH. Effect of presowing treatments, desiccation and storage conditions on germination of Strychnos nux-vomica seeds, a valuable medicinal plant. New Forest, 32: 121-131 (2006).

29. L. KAMBIZIA, P.O. ADEBOLAB, A.J. AFOLAYANA. Effects of temperature, pre-chilling and light on seed germination of Withania somnifera, a high value medicinal plant. S. Afr. J. Bot., 72: 11-14 (2006).

30. M.G. KULKARNI, R.A. STREET, J. VAN STADEN. Germination and seedling growth requirements for propagation of Dioscorea dregeana (Kunth) Dur. and Sching - a tuberous medicinal plant. S. Afr. J. Bot., 73: 131-137 (2007).

31. Z.K. FARIMAN, M. AZIZI, S. NOORI. Seed germination and dormancy breaking techniques for Echinacea purpurea L. J. Biol. Environ. Sci., 5(13): 7-107 (2011).

32. J.R. HILTON. The influence of light and potassium nitrate on the dormancy and germination of Avena fatua L. (wild oat) seed and its ecological significance. New Phytologist, 96(1): 31-34 (1984).

33. C. ÇIRAK, K. KEVSEROĞLU, A.K. AYAN. Breaking of seed dormancy in a Turkish endemic Hypericum species: Hypericum aviculariifolium subsp. Depilatum var. depilatum by light and some pre-soaking treatments. J. Arid. Environ., 68(1): 159-164 (2007).

34. N.G. TZORTZAKIS. Effect of pre-sowing treatment on seed germination and seedling vigor in endive and chicory. Hort. Sci., 36(3): 117-125 (2009).

35. A. TAVILI, A. FARAJOLLAHI, H. POUZESH, E. BANDAK. Treatment induced germination improvement in medicinal species of Foeniculum vulgare miller and Cuscuta epithymum (L.) L. Journal of Modern Applied Science, 4(7): 163-169 (2010). 